\begin{abstract}
Iranica
Abstracta Iranica Revue bibliographique pour le domaine irano-aryen

Volume 32-33 | 2013

Comptes rendus des publications de 2009-2010
\end{abstract}

\title{
Ato Akhrorov. Tadzhikskoe kino: 1969-1974
}

\section{Evelin Grassi}

\section{(2) OpenEdition}

\section{Journals}

Electronic version

URL: http://journals.openedition.org/abstractairanica/40157

DOI: 10.4000/abstractairanica.40157

ISSN: 1961-960X

\section{Publisher:}

CNRS (UMR 7528 Mondes iraniens et indiens), Éditions de l'IFRI

\section{Printed version}

Date of publication: 1 December 2013

ISSN: 0240-8910

\section{Electronic reference}

Evelin Grassi, « Ato Akhrorov. Tadzhikskoe kino: 1969-1974», Abstracta Iranica [Online], Volume 32-33 |

2013, document 469, Online since 01 July 2016, connection on 04 October 2020. URL : http://

journals.openedition.org/abstractairanica/40157 ; DOI : https://doi.org/10.4000/abstractairanica. 40157

This text was automatically generated on 4 October 2020.

Tous droits réservés 


\title{
Ato Akhrorov. Tadzhikskoe kino: 1969-1974
}

\author{
Evelin Grassi
}




\section{REFERENCES}

Ato Akhrorov. Tadzhikskoe kino: 1969-1974 gg. Dushanbe, Donish, 2010, 166 p., filmography p. 146-165. [Tajik Cinema: 1969-1974]

1 This book in Russian follows an earlier study by Ato Akhrorov published in 1971 under the title Tadzhikskoe kino: 1929-1969 (Dushanbe, Donish, 230p., filmography, p. 212-228). Each chapter is devoted to two or three significant Tajik films from the period 1969-1974, and organized so as to introduce leitmotifs such as: the social basis of the historical and revolutionary themes chosen for the films (p. 58-71), the lack of young film-makers (p. 43-50) and the spread of television musical comedies (p. 97-118).

Among the films celebrating Tajik-Persian literature and men of letters, we might mention Skazanie o Rustame [The story of Rostam, 1970, two episodes] and Rustam $i$ Sukhrab [Rostam and Sohrab, 1971, two episodes], both adapted from the Shāhnāma of Ferdowsi by G. Koltunov and directed by B. Kimyagarov (p. 78-96). Another example is Zvezda v nochi [A star in the night, 1972] on the life of Ahmad Donish (1826/7-1897), - a renowned man of letters and representative of the Persian Enlightenment in Bukhara adapted by the Tajik scholar Rasul Hodizoda and directed by A. Rakhimov and I. Usov (p. 72-77).

3 It is worth pointing out that no mention is made of dubbing films from Russian in Tajik, a process that started in the late 1990s after the breakup of the Soviet Union. This occurred in: the episodes adapted from the Shāhnāma; the film on Ahmad Donish, which became Sitorae dar tirashab [A star in the darkness of night] in Tajik - the title would then be borrowed by Rasul Hodizoda for his novel (Dushanbe, Irfon, 1983); and the film Tret'ya doch' [The third daughter, 1970] or Dukhtari seyum in Tajik, adapted by the Tajik writer Foteh Niyozī and directed by A. Turaev.

\section{AUTHORS}

\section{EVELIN GRASSI}

Université de Naples 